\title{
Sphenopalatine Foramen Localization: Radiological and Surgical Morphometric Analysis for Localization of Sphenopalatine Artery
}

\author{
Original Essam Abdelwanees Behairy, Ahmed Abdelhalim Mohamed, Hany Ibrahim Attya \\ Article Ibrahim, Ashraf Ali Eldemerdash \\ Department of Otorhinolaryngology, Faculty of Medicine, Menoufia University, Menoufia, \\ Egypt.
}

\begin{abstract}
Objectives: To compare between radiological \& surgical measurements for landmarks of the sphenopalatine foramen. Background: Transnasal endoscopic sphenopalatine artery ligation is becoming the procedure of choice for surgical management of severe intractable posterior epistaxis. Establishment of landmarks for localization of the sphenopalatine foramen can help rapid surgical exposure of the sphenopalatine artery for its ligation.

Patients and Methods: This study is a cross sectional comparative study, in which we had established landmarks for localization of sphenopalatine foramen (SPF); Radiologically \& Surgically during endoscopic sinonasal surgeries. Patients for this study were selected from otorhinolaryngology department, Menoufia University. Distances were measured between five simple endoscopic landmarks and the sphenopalatine foramen radiological before surgeries and during surgical procedures. Results were collected, tabulated and statistically analyzed by an IBM compatible personal computer with SPSS statistical package version 23.

Results: The mean (standard deviation [SD]) anteroposterior distances to the sphenopalatine foramen were the following: Choanal arch radiologically (-9.49 \pm 0.545$)$ \& surgically (-9.25 \pm 0.555$)$, maxillary line $(38.51 \pm 2.34)$ same radiologically \& surgically. Anterior head of middle turbinate (34.88 1.84$)$ same radiologically \& surgically, basal lamella radiologically $(11.13 \pm 0.961) \&$ surgically (10.09 \pm 0.676$)$. The mean (SD) distance in the vertical dimension from the nasal floor was same radiologically \& surgically $(27.25 \pm 1.33)$. Right and left-sided measurements were similar. Female patients had statistically shorter distances to sphenopalatine foramen from the maxillary line and anterior head of the middle turbinate. Conclusion: Radiological measurements from the SPF to maxillary line, anterior head of middle turbinate and nasal floor are reliable with surgical measurements for both sexes so, these radiological measures can help rapid estimation and localization of the SPF in cases of posterior epistaxis to facilitate rapid transnasal endoscopic sphenopalatine artery ligation (TESPAL).
\end{abstract}

Key Words: Epistaxis, sphenopalatine artery, Sphenopalatine foramen.

Received: 22 March 2021, Accepted: 25 April 2021

Corresponding Author: Hany Ibrahim Attya Ibrahim, M.S., Department of Otorhinolaryngology, Faculty of Medicine, Menoufia University, Menoufia, Egypt., Tel.: 00201143314060,E-mail: drhanyfadanent@gmail.com

ISSN: 2090-0740, 2021

\section{INTRODUCTION}

Epistaxis is the most common otolaryngologic emergency which occurs approximately in $10 \%$ of population. ${ }^{[5,8,16]}$ More than $90 \%$ of epistaxis cases originate anteriorly from Kiesselbach,s plexus over the anterior nasal septum. However, most severe intractable cases arise posteriorly. ${ }^{[3]}$ The sphenopalatine artery (SPA) is a terminal branch of the internal maxillary artery (IMA) supplies blood to lateral nasal wall, inferior and middle turbinates and the posterior septum and is implicated in most cases of posterior epistaxis. ${ }^{[3,16]}$ When addressing the key distal branch of the relevant external carotid circulation, transnasal endoscopic SPA ligation (TESPAL) has become the procedure of choice for intractable epistaxis due to its efficacy, favorable risk-benefit ratio and cost-effectiveness. ${ }^{[16,18]}$ Sphenopalatine surgery was once an extremely difficult method. Endoscopic surgery has made progress with improvement of instruments available for surgery. Therefore, an increasing number of surgeons perform endoscopic sphenopalatine surgery and it has become an important method to control severe epistaxis. The location of the sphenopalatine foramen (SPF) is identified within the superior meatus after elevation of a mucoperiosteal flap and identification of the crista ethmoidalis from the posterior aspect of the middle meatus. The sphenopalatine foramen (SPF) represents an opening on the lateral nasal wall that is present at the articulation between the superior aspect of the vertical portion of the sphenopalatine bone and the inferior projection of the sphenoid bone. ${ }^{[10]}$ The sphenopalatine foramen connects the nasal cavity to the pterygopalatine fossa of the skull and houses the sphenopalatine artery (SPA) and vein, the posterior superior lateral nerve and the nasopalatine 
nerves. ${ }^{[6]}$ Difficulty in locating the SPA as it exits the SPF may be accompanied by active bleeding that obscures the operative field or oedematous and friable tissue caused by previous nasal packing. As such, the addition of surgical landmarks to locate the SPF will be helpful beyond the traditional reliance on the crista ethmoidalis to establish a direct and rapid localization for SPA in cases of refractory epistaxis. The aim of this study is to establish simple endoscopic landmarks to facilitate transnasal endoscopic sphenopalatine artery ligation (TESPAL).

\section{PATIENTS AND METHODS:}

This study is a cross sectional comparative study in which we had established landmarks for localization of sphenopalatine foramen (SPF); Radiologically \& Surgically during endoscopic sinonasal surgeries. Patients for this study were selected from otorhinolaryngology department, Menoufia University with ethics approval \& consent. Patients for this study were selected according to the following inclusion criteria: Adult patients with posterior epistaxis and patients who were prepared for endoscopic sinonasal surgery, but children patients, patients with evidence of previous sinus, nasal, or skull base surgery and patients with significant obscuring sinonasal pathology are excluded. Cases were divided into two equal groups according to sex.
Methods:

Multislice CTs without contrast had been performed to all patients according to a standard clinical protocol in which 1-1.5 mm images were acquired, axial and coronal reconstructions were created. The distance from the SPF to the following surgical landmarks had been measured bilaterally: nasal floor, choanal arch, maxillary line, anterior head of the middle turbinate, and the basal lamella of the middle turbinate. These landmarks were selected for their consistent and reliable identification during nasal endoscopy and CT examination. Both axial and coronal CT sinus images were reviewed to locate each landmark and the distances were measured. Distances to the SPF in the anteroposterior dimension were recorded for all except the nasal floor, which was recorded in the vertical dimension. Mean distances and standard deviations (SD) were calculated; laterality and sex group comparisons were made by using paired and unpaired two-tailed Student,s ttest, respectively.

\section{Preoperative Assessment:}

History taking, endoscopic nasal examination, CT Nose \& PNS without contrast 1-1.5 mm sections, routine laboratory tests, all done for each case. (b)

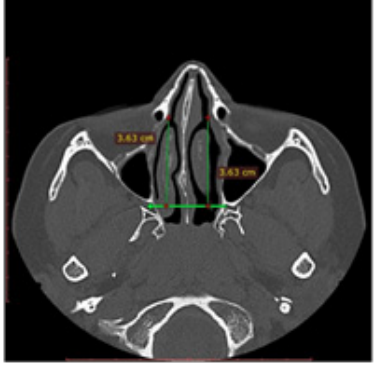

(d)

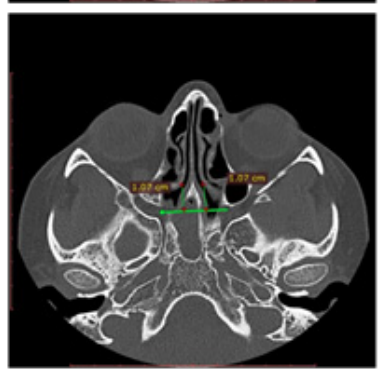

(c)

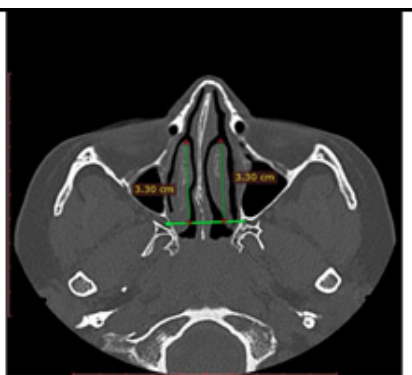

(a)

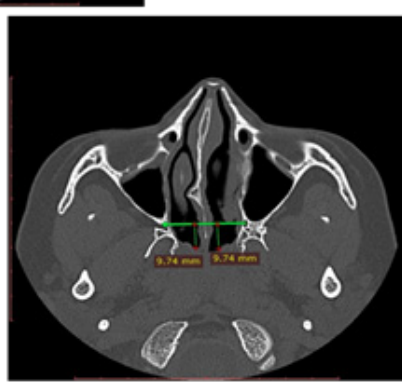

(e)

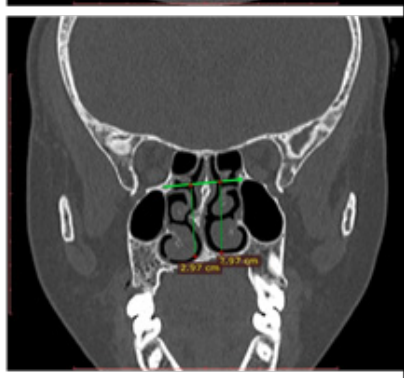

Fig. 1: Representative computed tomography measurements from landmarks of our study to the sphenopalatine foramen (SPF); (a) Anterior head of middle turbinate; (b) Maxillary line; (c) Choanal arch; (d) Basal lamella; (e) Nasal floor. 


\section{Surgical procedure:}

Each case in the study had its own surgical procedure because they are different in diagnosis. Some of them we did septoplasty, others turbinectomy, and FESS was done for others. In all of cases we measured distances from the selected mentioned five anatomic landmarks to the SPF in the surgical procedure. We used the expected distance from simple endoscopic landmarks to the SPF to triangulate the most likely location of the SPA. The anatomic landmarks in this study were chosen for easy identification during nasal endoscopy and their expected presence, even in the setting of previous surgery or trauma. The radiographic measurements described in this study had been used to guide incision placement and elevate a smaller flap directly onto the foramen or coagulate directly on top of it.

\section{Sample size calculation:}

Based on previous studies (May et al., 1994) who found that frequency of hemorrhage as a major complication of endoscopic sinus surgery was $(0.19 \%)$ and frequency of epistaxis as a minor complication was $(1.6 \%)$, so overall frequency of complications that need sphenopalatine artery ligation was (1.79\%). According to statistical unit of Menoufia University Hospitals, total number of emergency cases admitted to ENT department within 6 months (expected duration of the study) is about 208 cases ( 8 cases weekly). Calculated sample size for the current population survey study using Epi-info 7 program is 24 patients, they were selected from otorhinolaryngology emergency unit \& department, Menoufia University Hospital, with power of the study $80 \%$, acceptable margin of error $5 \%$ design effect 1 and confidence level 95\%.

Reference: May M, Levine HL, Mester SJ, Schaitkin B. Complications of endoscopic sinus surgery: analysis of 2108 patients-incidence and prevention. The Laryngoscope. 1994 Sep;104(9):1080-3.

\section{Statistical analysis:}

Statistical Analysis of the collected data: Results were collected, tabulated and statistically analyzed by an IBM compatible personal computer with SPSS statistical package version 23 (SPSS Inc. Released 2015. IBM SPSS statistics for windows, version 23.0, Armnok, NY: IBM Corp).
Two types of statistical analysis were done: Descriptive statistics e.g., Number (No), percentage (\%), mean $\left(\mathrm{X}^{-}\right)$ and standard deviation (SD). Arithmetic mean(x) was used as a measure of central tendency. Standard deviation (SD) was used as a measure of dispersion. Percentage (\%). Median was used as a measure of central tendency. Range was used as a measure of dispersion.

\section{Analytic statistics:}

Student t-test: is a test of significant used for comparison between two groups having quantitative variables and with independent parametric data.

$P$ value at 0.05 was used to determine significance regarding: $P$-value $>0.05$ to be statistically insignificant, $P$-value $\leq 0.05$ to be statistically significant, $P$-value $\leq 0.001$ to be highly statistically significant.

Reference: Introduction to biostatistics second edition “chap T. Le, Lynn. E. Eberly (2016).

\section{RESULTS:}

The mean (standard deviation [SD]) anteroposterior distances to the sphenopalatine foramen were the following: Choanal arch radiologically (-9.49 \pm 0.545$)$ \& surgically $(-9.25 \pm 0.555)$, maxillary line $(38.51 \pm 2.34)$ same radiologically \& surgically. Anterior head of middle turbinate $(34.88 \pm 1.84)$ same radiologically \& surgically, basal lamella radiologically $(11.13 \pm 0.961)$ \& surgically (10.09 \pm 0.676$)$. The mean (SD) distance in the vertical dimension from the nasal floor was same radiologically \& surgically (27.25 \pm 1.33$)$. Right and left-sided measurements were similar. Female patients had statistically shorter distances to sphenopalatine foramen from the maxillary line and anterior head of the middle turbinate. 
Table 1: Comparison between radiological and surgical measurement distances from landmarks to the SPF among studied patients

\begin{tabular}{|c|c|c|c|c|c|}
\hline & & $\begin{array}{c}\text { Radiological } \\
\text { measurements } \\
\mathrm{N}=24\end{array}$ & $\begin{array}{c}\text { Surgical } \\
\text { measurements } \\
\mathrm{N}=24\end{array}$ & t-test & $P$ value \\
\hline \multirow{2}{*}{$\begin{array}{l}\text { Choanal Arch } \\
\mathrm{X} \pm \mathrm{SD} \\
\text { Range } \\
\text { Median }\end{array}$} & Right & $\begin{array}{c}-9.49 \pm 0.545 \\
-10.9--8.43 \\
-9.42\end{array}$ & $\begin{array}{c}-9.25 \pm 0.555 \\
-10.20--8 \\
-9.26\end{array}$ & 1.50 & $\begin{array}{c}0.138 \\
\text { NS }\end{array}$ \\
\hline & Left & $\begin{array}{c}-9.50 \pm 0.545 \\
-10.9--8.43 \\
-9.42\end{array}$ & $\begin{array}{c}-9.25 \pm 0.555 \\
-10.20--8 \\
-9.26\end{array}$ & 1.50 & $\begin{array}{c}0.138 \\
\text { NS }\end{array}$ \\
\hline \multirow{2}{*}{$\begin{array}{l}\text { Maxillary Line } \\
\mathrm{X} \pm \mathrm{SD} \\
\text { Range } \\
\text { Median }\end{array}$} & Right & $\begin{array}{c}38.51 \pm 2.34 \\
35.60-42.50 \\
37.85\end{array}$ & $\begin{array}{c}38.51 \pm 2.34 \\
35.60-42.50 \\
37.85\end{array}$ & 0.00 & $\begin{array}{l}1.00 \\
\text { NS }\end{array}$ \\
\hline & Left & $\begin{array}{c}38.51 \pm 2.34 \\
35.60-42.50 \\
37.85\end{array}$ & $\begin{array}{c}38.51 \pm 2.34 \\
35.60-42.50 \\
37.85\end{array}$ & 0.00 & $\begin{array}{l}1.00 \\
\text { NS }\end{array}$ \\
\hline \multirow{2}{*}{$\begin{array}{l}\text { Anterior Head of } \\
\text { Middle Turbinate } \\
\mathrm{X} \pm \mathrm{SD} \\
\text { Range } \\
\text { Median }\end{array}$} & Right & $\begin{array}{c}34.88 \pm 1.84 \\
31-38.6 \\
35.10\end{array}$ & $\begin{array}{c}34.88 \pm 1.84 \\
31-38.6 \\
35.10\end{array}$ & 0.00 & $\begin{array}{l}1.00 \\
\mathrm{NS}\end{array}$ \\
\hline & Left & $\begin{array}{c}34.88 \pm 1.84 \\
31-38.6 \\
35.10\end{array}$ & $\begin{array}{c}34.88 \pm 1.84 \\
31-38.6 \\
35.10\end{array}$ & 0.00 & $\begin{array}{l}1.00 \\
\text { NS }\end{array}$ \\
\hline \multirow{2}{*}{$\begin{array}{l}\text { Basal Lamella of } \\
\text { Middle Turbinate } \\
\mathrm{X} \pm \mathrm{SD} \\
\text { Range } \\
\text { Median }\end{array}$} & Right & $\begin{array}{c}11.13 \pm 0.961 \\
8.7-12.5 \\
11.30\end{array}$ & $\begin{array}{c}10.09 \pm 0.676 \\
8.90-11.50 \\
10.10\end{array}$ & 4.32 & $\begin{array}{c}<0.001 \\
\text { HS }\end{array}$ \\
\hline & Left & $\begin{array}{c}11.13 \pm 0.961 \\
8.7-12.5 \\
11.30\end{array}$ & $\begin{array}{c}10.09 \pm 0.676 \\
8.90-11.50 \\
10.10\end{array}$ & 4.32 & $\begin{array}{c}<0.001 \\
\mathrm{HS}\end{array}$ \\
\hline \multirow{2}{*}{$\begin{array}{l}\text { Nasal Floor } \\
\mathrm{X} \pm \mathrm{SD} \\
\text { Range } \\
\text { Median }\end{array}$} & Right & $\begin{array}{c}27.25 \pm 1.32 \\
25.10-29.7 \\
27\end{array}$ & $\begin{array}{c}27.25 \pm 1.33 \\
25.1-29.7 \\
27\end{array}$ & 0.00 & $\begin{array}{l}1.00 \\
\text { NS }\end{array}$ \\
\hline & Left & $\begin{array}{c}27.25 \pm 1.32 \\
25.10-29.7 \\
27\end{array}$ & $\begin{array}{c}27.25 \pm 1.33 \\
25.1-29.7 \\
27\end{array}$ & 0.00 & $\begin{array}{l}1.00 \\
\mathrm{NS}\end{array}$ \\
\hline
\end{tabular}

$\mathrm{X}$ : Mean, SD: standard deviation $\mathrm{t}$ : student's t test

\section{Basal Lamella Of Middle Turbinate}

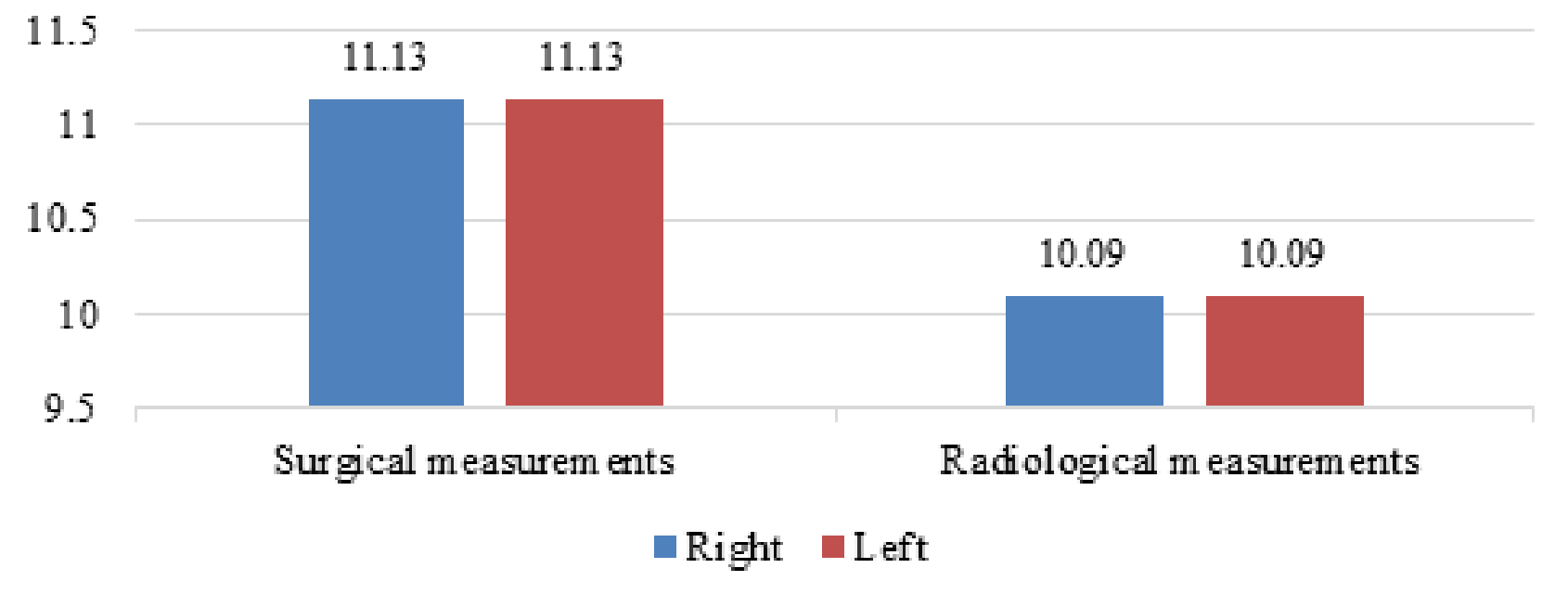

Fig. 2: Comparison between surgical and radiological measurements of the basal lamella which is highly significant different and so, considered a non reliable radiological measure for surgical guidance. 
Table 2: Comparison of radiological measurement distances from landmarks to the SPF among studied patients as regard sex

\begin{tabular}{|c|c|c|c|c|c|}
\hline & & \multicolumn{2}{|c|}{ Radiological measurements } & \multirow[t]{2}{*}{$\mathrm{t}$-test } & \multirow[t]{2}{*}{$P$ value } \\
\hline & & $\begin{array}{c}\text { Male } \\
\text { No=12 }\end{array}$ & $\begin{array}{l}\text { Female } \\
\mathrm{No}=12\end{array}$ & & \\
\hline \multirow{2}{*}{$\begin{array}{l}\text { Choanal Arch } \\
\mathrm{X} \pm \mathrm{SD} \\
\text { Range } \\
\text { Median }\end{array}$} & Right & $\begin{array}{c}-9.65 \pm 0.500 \\
-10.2--8.34 \\
-9.85\end{array}$ & $\begin{array}{c}-9.33 \pm 0.561 \\
-10.9--8.73 \\
-9.23\end{array}$ & 1.47 & $\begin{array}{c}0.154 \\
\text { NS }\end{array}$ \\
\hline & Left & $\begin{array}{c}--9.65 \pm 0.500 \\
-10.2--8.34 \\
-9.85\end{array}$ & $\begin{array}{c}-9.33 \pm 0.561 \\
-10.9--8.73 \\
-9.23\end{array}$ & 1.47 & $\begin{array}{c}0.154 \\
\text { NS }\end{array}$ \\
\hline \multirow{2}{*}{$\begin{array}{l}\text { Maxillary Line } \\
\mathrm{X} \pm \mathrm{SD} \\
\text { Range } \\
\text { Median }\end{array}$} & Right & $\begin{array}{c}40.45 \pm 1.72 \\
38.10-42.50 \\
40.50\end{array}$ & $\begin{array}{c}36.57 \pm 0.562 \\
35.6-37.6 \\
36.50\end{array}$ & 7.43 & $\begin{array}{c}<0.001 \\
\text { HS }\end{array}$ \\
\hline & Left & $\begin{array}{c}40.45 \pm 1.72 \\
38.10-42.50 \\
\quad 40.50\end{array}$ & $\begin{array}{c}36.57 \pm 0.562 \\
35.6-37.6 \\
36.50\end{array}$ & 7.43 & $\begin{array}{c}<0.001 \\
\mathrm{HS}\end{array}$ \\
\hline \multirow{2}{*}{$\begin{array}{l}\text { Anterior Head of } \\
\text { Middle Turbinate } \\
\mathrm{X} \pm \mathrm{SD} \\
\text { Range } \\
\text { Median }\end{array}$} & Right & $\begin{array}{c}35.70 \pm 1.92 \\
32.8-38.6 \\
36.1\end{array}$ & $\begin{array}{c}34.06 \pm 1.38 \\
31-35.70 \\
33.85\end{array}$ & 2.39 & $\begin{array}{c}0.026 \\
\mathrm{~S}\end{array}$ \\
\hline & Left & $\begin{array}{c}35.70 \pm 1.92 \\
32.8-38.6 \\
36.1\end{array}$ & $\begin{array}{c}34.06 \pm 1.38 \\
31-35.70 \\
33.85\end{array}$ & 2.39 & $\begin{array}{c}0.026 \\
\mathrm{~S}\end{array}$ \\
\hline \multirow{2}{*}{$\begin{array}{l}\text { Basal Lamella of } \\
\text { Middle Turbinate } \\
\mathrm{X} \pm \mathrm{SD} \\
\text { Range } \\
\text { Median }\end{array}$} & Right & $\begin{array}{c}11.85 \pm 0.405 \\
11.30-12.50 \\
11.80\end{array}$ & $\begin{array}{c}10.42 \pm 0.810 \\
8.70-11.30 \\
10.70\end{array}$ & 5.45 & $\begin{array}{c}<0.001 \\
\text { HS }\end{array}$ \\
\hline & Left & $\begin{array}{c}11.85 \pm 0.405 \\
11.30-12.50 \\
11.80\end{array}$ & $\begin{array}{c}10.42 \pm 0.810 \\
8.70-11.30 \\
10.70\end{array}$ & 5.45 & $\begin{array}{c}<0.001 \\
\text { HS }\end{array}$ \\
\hline \multirow{2}{*}{$\begin{array}{l}\text { Nasal Floor } \\
\mathrm{X} \pm \mathrm{SD} \\
\text { Range } \\
\text { Median }\end{array}$} & Right & $\begin{array}{c}27.50 \pm 1.32 \\
25.10-29.70 \\
27.20\end{array}$ & $\begin{array}{c}27 \pm 1.34 \\
25.20-29.7 \\
26.70\end{array}$ & 0.902 & $\begin{array}{c}0.377 \\
\text { NS }\end{array}$ \\
\hline & Left & $\begin{array}{c}27.50 \pm 1.32 \\
25.10-29.70 \\
27.20\end{array}$ & $\begin{array}{c}27 \pm 1.34 \\
25.20-29.7 \\
26.70\end{array}$ & 0.902 & $\begin{array}{c}0.377 \\
\text { NS }\end{array}$ \\
\hline
\end{tabular}

$\mathrm{X}$ : Mean, SD: standard deviation t: student's t test

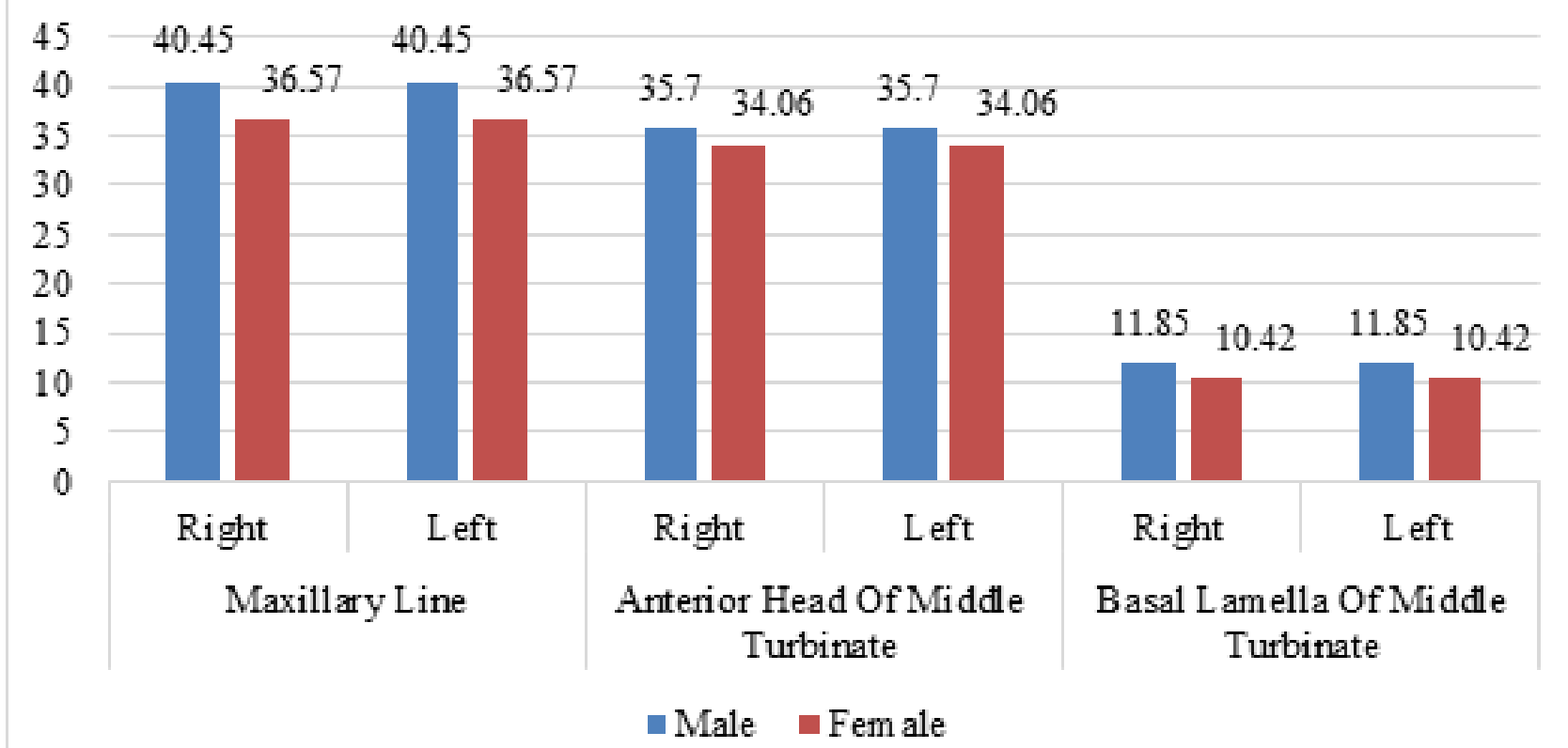

Fig. 3: Comparison between landmarks which have a significant difference in radiological measures as regard sex 
Table 3: Comparison of surgical measurement distances from landmarks to the SPF among studied patients as regard sex

\begin{tabular}{|c|c|c|c|c|c|}
\hline & & \multicolumn{2}{|c|}{ Surgical measurements } & \multirow[t]{2}{*}{ t-test } & \multirow[t]{2}{*}{$P$ value } \\
\hline & & $\begin{array}{c}\text { Male } \\
\mathrm{No}=12\end{array}$ & $\begin{array}{l}\text { Female } \\
\mathrm{No}=12\end{array}$ & & \\
\hline \multirow{2}{*}{$\begin{array}{l}\text { Choanal Arch } \\
\mathrm{X} \pm \mathrm{SD} \\
\text { Range } \\
\text { Median }\end{array}$} & Right & $\begin{array}{c}-9.24 \pm 0.686 \\
-10.20--8 \\
-9.25\end{array}$ & $\begin{array}{c}-9.26 \pm 0.451 \\
-10--8.2 \\
-9.26\end{array}$ & 0.079 & $\begin{array}{c}0.938 \\
\text { NS }\end{array}$ \\
\hline & Left & $\begin{array}{c}-9.24 \pm 0.686 \\
-10.20--8 \\
-9.25\end{array}$ & $\begin{array}{c}-9.26 \pm 0.451 \\
-10--8.2 \\
-9.26\end{array}$ & 0.079 & $\begin{array}{c}0.938 \\
\text { NS }\end{array}$ \\
\hline \multirow{2}{*}{$\begin{array}{l}\text { Maxillary Line } \\
\mathrm{X} \pm \mathrm{SD} \\
\text { Range } \\
\text { Median }\end{array}$} & Right & $\begin{array}{c}40.45 \pm 1.72 \\
38.1-42.5 \\
40.45\end{array}$ & $\begin{array}{c}36.50 \pm 0.630 \\
35.6-37.6 \\
36.45\end{array}$ & 7.47 & $\begin{array}{c}<0.001 \\
\text { HS }\end{array}$ \\
\hline & Left & $\begin{array}{c}40.45 \pm 1.72 \\
38.1-42.5 \\
40.45\end{array}$ & $\begin{array}{c}36.50 \pm 0.630 \\
35.6-37.6 \\
36.45\end{array}$ & 7.47 & $\begin{array}{c}<0.001 \\
\text { HS }\end{array}$ \\
\hline \multirow{2}{*}{$\begin{array}{l}\text { Anterior Head of } \\
\text { Middle Turbinate } \\
\mathrm{X} \pm \mathrm{SD} \\
\text { Range } \\
\text { Median }\end{array}$} & Right & $\begin{array}{c}35.70 \pm 1.92 \\
32.80-38.60 \\
36.10\end{array}$ & $\begin{array}{c}34.06 \pm 1.38 \\
31-35.70 \\
33.85\end{array}$ & 2.39 & $\begin{array}{c}0.025 \\
\mathrm{~S}\end{array}$ \\
\hline & Left & $\begin{array}{c}35.70 \pm 1.92 \\
32.80-38.60 \\
36.10\end{array}$ & $\begin{array}{c}34.06 \pm 1.38 \\
31-35.70 \\
33.85\end{array}$ & 2.39 & $\begin{array}{c}0.025 \\
\mathrm{~S}\end{array}$ \\
\hline \multirow{2}{*}{$\begin{array}{l}\text { Basal Lamella of } \\
\text { Middle Turbinate } \\
\mathrm{X} \pm \mathrm{SD} \\
\text { Range } \\
\text { Median }\end{array}$} & Right & $\begin{array}{c}10.21 \pm 0.505 \\
9.50-11 \\
10.10\end{array}$ & $\begin{array}{c}9.98 \pm 0.820 \\
8.9-11 \\
10.05\end{array}$ & 0.833 & $\begin{array}{c}0.414 \\
\text { NS }\end{array}$ \\
\hline & Left & $\begin{array}{c}10.21 \pm 0.505 \\
9.50-11 \\
10.10\end{array}$ & $\begin{array}{c}9.98 \pm 0.820 \\
8.9-11 \\
10.05\end{array}$ & 0.833 & $\begin{array}{c}0.414 \\
\text { NS }\end{array}$ \\
\hline \multirow{2}{*}{$\begin{array}{l}\text { Nasal Floor } \\
\mathrm{X} \pm \mathrm{SD} \\
\text { Range } \\
\text { Median }\end{array}$} & Right & $\begin{array}{c}27.50 \pm 1.32 \\
25.1-29.7 \\
27.10\end{array}$ & $\begin{array}{c}27 \pm 1.34 \\
25.2-29.7 \\
26.70\end{array}$ & 0.902 & $\begin{array}{c}0.377 \\
\text { NS }\end{array}$ \\
\hline & Left & $\begin{array}{c}27.50 \pm 1.32 \\
25.1-29.7 \\
27.10\end{array}$ & $\begin{array}{c}27 \pm 1.34 \\
25.2-29.7 \\
26.70\end{array}$ & 0.902 & $\begin{array}{c}0.377 \\
\text { NS }\end{array}$ \\
\hline
\end{tabular}

$\mathrm{X}$ : Mean, SD: standard deviation t: student's t test

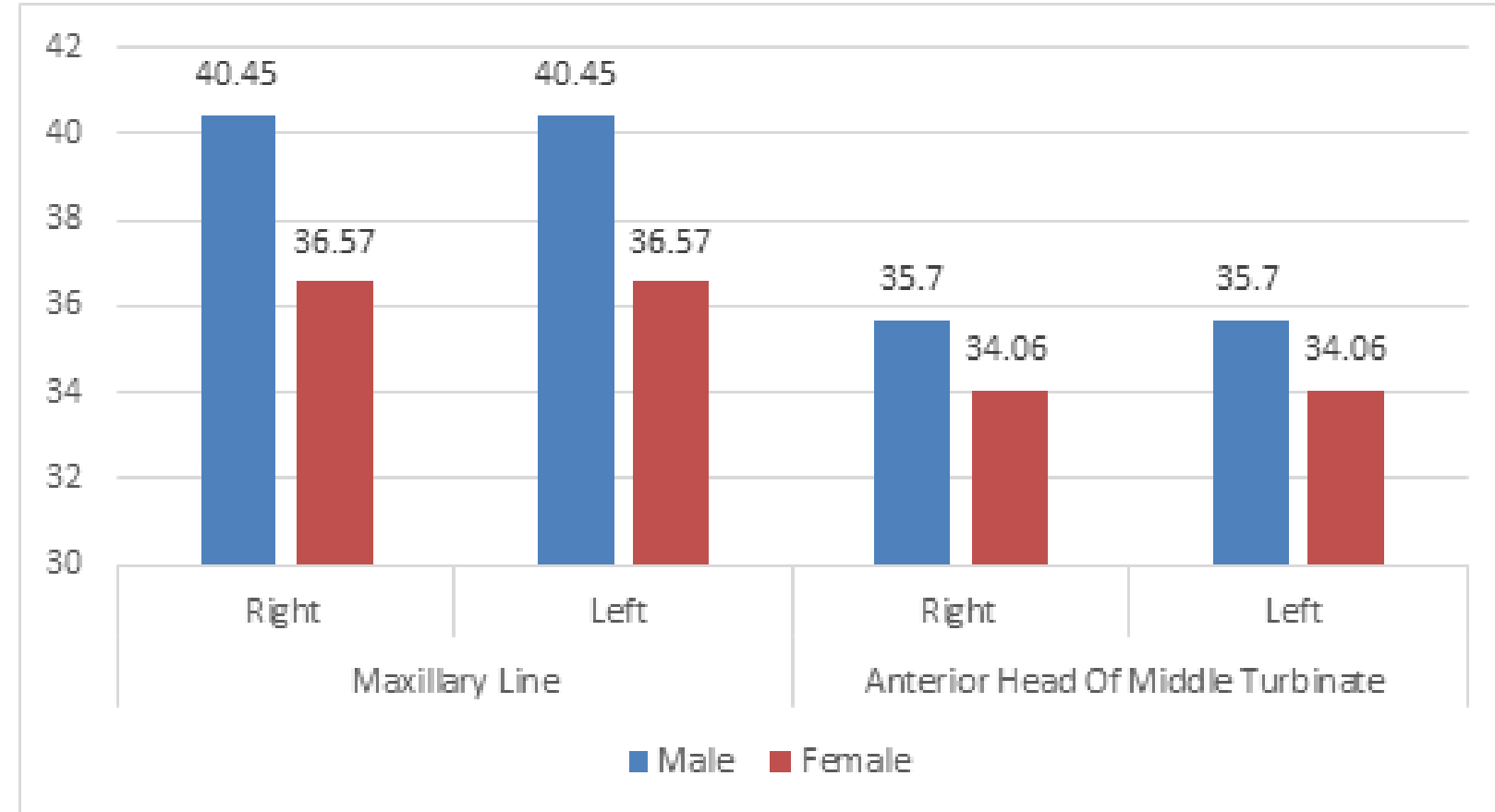

Fig. 4: Comparison between landmarks which have a significant difference in surgical measures as regard sex 


\section{DISCUSSION}

The sphenopalatine artery is the largest branch of the maxillary artery. It is located within the pterygopalatine fossa and passes through the sphenopalatine foramen (SPF) on the lateral nasal wall. Epistaxis from this artery is potentially life threatening and may urgently require endonasal endoscopic occlusion. ${ }^{[14]}$ Intractable posterior epistaxis may be managed either by arterial ligation or embolization of the SPA because these procedures have higher patient satisfaction, increased efficacy and cost savings when compared with traditional posterior packing and observation. ${ }^{[3]}$ As an alternative to surgical intervention, transcutaneous embolization remains a reasonable choice for poor surgical candidates or when surgical expertise is not available. However, rare but devastating risks accompany embolization procedures, including stroke, facial pain \& paresthesias, ophthalmoplegia, blindness and soft-tissue necrosis, all while carrying a higher recurrence rate for epistaxis $(20 \%)$ than TESPAL procedures. ${ }^{[18]}$ The preferred surgical procedure for epistaxis management has evolved over time. Previous surgical methods to control posterior epistaxis relied on transantral ligation of the IMA, however, this procedure has been associated with significant morbidity, including sinusitis, facial pain or edema, infraorbital nerve paresthesia and oroantral fistula. ${ }^{[11]}$ In addition, pterygopalatine fossa dissection carries rare risks of blindness, ophthalmoplegia, decreased lacrimation and hematoma and yet, transantral IMA ligation still carries an $10 \%$ rate of recurrent epistaxis. ${ }^{[17]}$ Choosing the endoscopy is a safe manipulation to observe SPF due to the fact that this foramen is small and lies at the middle part of the skull base and is difficult to reach by classic surgical procedures in addition to the less complication in using this technique. ${ }^{[1]}$ Transnasal approach is performed because it offers easy accessibility to the foramen, avoids external incisions, osteotomies and bone resection required in open procedures. ${ }^{[4]} \mathrm{A}$ microsurgical approach to SPA ligation was first described by Prades 12 in 1976 and later Budrovich and Saetti13 described the endoscopic approach to SPA ligation. Since then, this has become the procedure of choice due to its efficacy, rarity of minor complications and cost-effectiveness. ${ }^{[16]}$ In current study, we compared between radiological and surgical measurments from fixed landmarks to the SPF to select the most significant landmark(s) for localization of the SPF to be a guide for rapid TESPAL. Our study is composed of 24 patients divided according to sex into two equal groups which were prepared for endoscopic sinonasal surgeries. We selected fixed landmarks to the SPF and we measured distances from these landmarks on CTs before surgeries. These landmarks are: maxillary line, anterior head of middle turbinate, basal lamella, nasal floor and the choanal arch. These landmarks were selected for their consistent and reliable identification during nasal endoscopy and CT examination. We measured distances from certain anatomic landmarks to the SPF radiologically and surgically in totally 24 patients. According to our measures, we found that the mean (standard deviation [SD]) anteroposterior distances to the sphenopalatine foramen were the following: Choanal arch radiologically $(-9.49 \pm 0.545)$ \& surgically $(-9.25 \pm 0.555)$, maxillary line $(38.51 \pm 2.34)$ same radiologically \& surgically. Anterior head of middle turbinate $(34.88 \pm 1.84)$ same radiologically \& surgically, basal lamella radiologically $(11.13 \pm 0.961)$ $\&$ surgically $(10.09 \pm 0.676)$. The mean (SD) distance in the vertical dimension from the nasal floor was same radiologically \& surgically $(27.25 \pm 1.33)$. Right and left-sided measurements were similar. Female patients had statistically shorter distances to sphenopalatine foramen from the maxillary line and anterior head of the middle turbinate. By analysis of results we found that measures were same radiologically and surgically for maxillary line, anterior head of middle turbinate and nasal floor with non-significant difference between radiological measures and surgical measures. So, these three landmarks are the most reliable landmarks which can be taken as a guide for rapid localization for the SPF in surgeries for TESPAL. For the choanal arch measures were same in 11 patients of totally 24 patients, but different between radiological measures and surgical measures in the other 13 patients but still a non significant difference. For the basal lamella, the radiological measures are totally different from surgical measures. So, the radiological measurement of the distance from the basal lamella to the SPF on CT is the least reliable measure to be taken as a guide for proper surgical localization of the SPF. Based on our measurements, we proposed using the expected distances from simple endoscopic landmarks to the SPF to triangulate the most likely location of the SPA. The reliable radiographic measurements described in this study can be used to guide incision placement and elevate a smaller flap directly onto the foramen or coagulate directly on top of it. The anatomic landmarks in this study were chosen for easy identification during nasal endoscopy and their expected presence, even in the setting of previous surgery or trauma. Distances were greater in male patients for most measurements, consistent with the larger mean nasal cavity dimensions typically seen in men. Scanavine et al. observed also in studying the location of the sphenopalatine foramen on the lateral nasal wall relative to the bony crest of middle nasal turbinate revealed that in $81 \%$ the bony crest of the middle nasal turbinate pointed to the inferior border of the SPF placing it in the superior nasal meatus. In $14.8 \%$ the bony crest of the middle nasal turbinate pointed to the middle of the 
sphenopalatine foramen placing it between the middle nasal meatus and the superior nasal meatus. In $1.8 \%$ the bony crest of the middle nasal turbinate pointed to the superior border of the SPF placing it in the middle nasal meatus. Identification of the site was not possible in one case. ${ }^{[4]}$ Herrera Tolosana et al. studied 32 halfskulls and accurately described the location of the SPF. In their sample, the most superior portion of the SPF was located at the same level as the higher portion of the choana in $62.5 \%$ of the cases. The other $32.5 \%$ had the medial portion of the SPF on the same level as the higher portion of the choana.$^{[9]}$ Rezende et al. reported that the accessory SPF was seen in $21 \%$ of their cases $^{[15]}$ More than that, they mentioned that most nasal fossae of their cases presented a single bilateral arterial trunk emerging from the SPF and in other cases, arterial trunks emerged bilaterally from the SPF. However, if its position on the lateral nasal wall is established by the relation with the ethmoidal crest of the palatine bone, onto which it joins the posterior portion of the middle nasal concha, other studies locate it in the middle and/or superior nasal meatuses. ${ }^{[17]}$ The latter author mentioned that apart from the comments about the bony crest of the middle nasal turbinate. It was also noted that in 30 specimens $(55.6 \%)$, the bony crest of the superior nasal turbinate was pointing towards the superior border of the sphenopalatine foramen. ${ }^{[12]}$ In addition, ethmoidal crest was present in $100 \%$ of the cadavers, being anterior to the SPF in $98.4 \%$ of the cases the most frequent SPF location was the transition of the middle and superior meatuses $(86.9 \%)^{[13]}$ Contrary, Alherabi et al. declared that since SPF frequently extends below ethmoidal crest, the mucoperiosteal flap should be extended below the inferior edge of this crest to avoid missing the middle meatal part of SPF any accessory foramina. ${ }^{[2]}$ Identifying the bony ethmoidal crest of the palatine bone, onto which the middle nasal turbinate is linked, is an anatomical and surgical landmark for locating the SPF in an 11 endonasal access. ${ }^{[7]}$ Their results revealed that in 44 specimens $(83 \%)$ the distal tip of the bony crest of the middle nasal turbinate pointed towards the inferior margin of the SPF, locating it in the superior nasal meatus; the SPF was located between the superior and middle nasal meatuses in eight specimens (15.1\%) and the foramen was fully located in the middle meatus in only one specimen $(1.9 \%)$. In current study, we selected other landmarks beyond the crista ethmoidalis to help rapid localization of the SPF in cases of TESPAL. In current study, we made a comparison between males and females for each landmark selected in this study radiologically and surgically and according to tables (2) \& (3) we found that measures are greater in males than in females for all measures with a significant difference for maxillary line, anterior head of the middle turbinate, and highly significant difference for the basal lamella. Another comparison was done for each case to all landmarks according to bilaterality radiologically and surgically and there was no difference in measurements. The mean distances described can serve as a useful tool for localization of the region of the SPF and can facilitate rapid surgical exposure.

\section{CONCLUSION}

Radiological measurements from the SPF to maxillary line, anterior head of middle turbinate and nasal floor are reliable with surgical measurements for both sexes so, these radiological measures can help rapid estimation and localization of the SPF in cases of posterior epistaxis to facilitate rapid transnasal endoscopic sphenopalatine artery ligation (TESPAL).

\section{CONFLICT OF INTEREST}

There are no conflicts of interest.

\section{REFERENCES}

1. Abuzayed B, Tanriover N, Gazioglu N. (2009): Extended endo $\neg$ scopic endonasal approach to the pterygopalatine fossa: anatomic study. J Neurosurg Sci.; 53(2): 37-44.

2. Alherabi A, Marglani O, Herzallah IR, Shaibah H, Alaidarous T, Alkaff H, et al. (2014): Endoscopic localization of the sphenopalatine foramen: do measurements matter? European Archives of OtoRhino-Laryngology.; Sep;271(9):2455-60.

3. Douglas R and Wormald PJ. (2007) Update on epistaxis. Curr Opin Otolaryngol Head Neck Surg; $15: 180-183$

4. Enepekides DJ. (2004): Recent advances in the treatment of juvenile angiofibroma. Curr Opin Otolaryngol Head Neck Surg.; 12(6): 495-499.

5. Feusi B, Holzmann D, Steurer J. (2005): Posterior epistaxis: systematic review on the effectiveness of surgical therapies. Rhinology.; 43:300-304.

6. Gao L, Zhou L, Dai Z, Huang X. (2017): The Endoscopic Prelacrimal Recess Approach to the Pterygopalatine Fossa and Infratemporal Fossa. J Craniofac Surg.;28(6):1589-1593.

7. Gui P, Zhou S, Liang W, Ji R, Fu M, Xie G. (2004): The study of microdissection of endoscopic transnasal surgery in the sphenopalatine foramen. Lin chuang er bi yan hou ke za zhi= Journal of clinical otorhinolaryngology.;18(10):606-8. 
8. Hadoura L, Douglas C, McGarry GW, Young D. (2009): Mapping surgical coordinates of the sphenopalatine foramen: surgical navigation study. Journal of laryngology and otology.;123(7):742-5.

9. Herrera Tolosana SH, Liesa RF, Castellón JD, Delgado LP, Alquezar MP, Galve GT, et al. (2011): Sphenopalatinum foramen: an anatomical study. Acta Otorrinolaringologica (English Edition).;62(4):274-8.

10. Kim JH, Oka K, Jin ZW, Murakami G, RodríguezVázquez JF, Ahn SW, et al. (2017): Fetal Development of the Incisive Canal, Especially of the Delayed Closure Due to the Nasopalatine Duct: A Study Using Serial Sections of Human Fetuses. Anat Rec(Hoboken).; 300(6):1093-1103.

11. Kumar S, Shetty A, Rockey J, Nilssen E. (2003): Contemporary surgical treatment of epistaxis. What is the evidence for sphenopalatine artery ligation? Clin Otolaryngol Allied Sci; 28:360- 363.

12. Li J, Xu $\mathrm{X}$, Wang J, Jing $\mathrm{X}$, Guo Q, Qiu Y. (2009): Endoscopic Study for the Pterygopalatine Fossa Anatomy: Via the Middle Nasal MeatusSphenopalatine ForamenApproach. Journal of Craniofacial Surgery. 1;20(3):944-7.
13. Padua FG, Voegels RL. (2008): Severe posterior epistaxis-endoscopic surgical anatomy. Laryngoscope; 118:156-61

14. Prades JM, Asanau A, Timoshenko AP, Faye MB, Martin C. (2008): Surgical anatomy of the sphenopalatine foramen and its arterial content. Surgical and radiologic anatomy.; 1;30(7):583.

15. Rezende GL, Soares VY, Moraes WC, Oliveira CA Nakanishi M., (2012): The sphenopalatine artery: a surgical challenge in epistaxis. Braz J Otorhinolaryngol 2012; 78:42-7

16. Rudmik L and Smith TL. (2012): Management of intractable spontaneous epistaxis. Am J Rhinol Allergy.; 26:55- 60 .

17. Schwartzbauer HR, Shete M, Tami TA. (2003): Endoscopic anatomy of the sphenopalatine and posterior nasal arteries: Implications for the endoscopic management of epistaxis. Am J Rhinol; 17:63- 66.

18. Seno S, Arikata M, Sakurai H, Owaki S, Fukui J, Suzuki M, et al. (2009): Endoscopic ligation of the sphenopalatine artery and the maxillary artery for the treatment of intractable posterior epistaxis. American journal of rhinology \& allergy.; 23(2):197-9. 